\title{
The CityTree: a vertical plant wall
}

\author{
V. Splittgerber \& P. Saenger \\ Green City Solutions GmbH \& Co. KG, Germany
}

\begin{abstract}
Today, already over 50 per cent of the world's population is living in cities. Dwellers are suffering from syndromes such as stress, cancer and allergies caused by heat, noise and air pollution. Therefore, the CityTree has been developed. It is a vertical plant wall that filters the air, cools the surroundings and reduces noise. In combination with its potential to display advertisements, it is a marketing tool for companies. As a result, we provide clean and cool air which is economically profitable.

Keywords: air pollution, climate protection, climate change, fine dust, nitrogen oxide, CityTree, sustainability, vertical plant wall, moss.
\end{abstract}

\section{Introduction: air pollution}

The aim of this study is to minimize health risks as a consequence of air pollution, which is the cause of "...more than 2 million premature deaths each year..." (WHO [1]). Hence, every 8th death worldwide is caused by air pollution. Over 50 per cent of the world's population is living in cities. Thus, dwellers are suffering from syndromes like stress, asthma allergies, bronchitis and cancer caused by heat, noise and air pollution. These environmental impacts are worsened by climate change.

Therefore, the European Union (EU) has determined critical values (2008/50/EG). Air pollution in cities consists of 90 per cent fine dust and 10 per cent ozone. The arrangement of 2005 (which was amended in 2008 and 2010) determined the following critical values for fine dust: PM (Particulate Matter) 10: $40 \mu \mathrm{g} / \mathrm{m}^{3}$, PM 2.5: $20 \mu \mathrm{m}^{3}$ [2]. 


\section{Fine dust}

In general, fine dust consists primarily of nitrogen compounds (e.g. [3]). The particulate matter is caused by a multitude of emission sources (e.g. [4]) and influenced by meteorology [5]. Relating to the different size fractionation of dusts it is possible to distinguish between PM 10, PM 2.5 and PM 0.1 [2].

\subsection{State of knowledge}

Fine dust or particulate matter implies health risks for humans [6, 7]. There are a multiple projects such as EUROCHAMP (www.eurochamp.org), BENEFITS OF URBAN GREEN SPACE (BUGS) or PROGREENCITY (www.progreencity. com) which demonstrate the effort from the European Union to reduce emissions. These arrangements often contain and expand the state of knowledge of air pollution and fine dust. In addition some of them provide approaches for new solutions.

As already mentioned, there are different size fractionations which are displayed in the following table.

Table 1: Classification of fine dust, referring to Federal Environment Agency [2].

\begin{tabular}{|l|l|l|}
\hline $\begin{array}{l}\text { PM }-10 \\
\text { (inhalable) }\end{array}$ & $\begin{array}{l}\text { PM }-2.5 \\
\text { (respirable) }\end{array}$ & $\begin{array}{l}\text { PM }-0.1 \\
\text { (ultrafine dust) }\end{array}$ \\
\hline $\begin{array}{l}\text { Particles with } \\
\text { aerodynamic diameters } \\
\text { smaller than } 10 \\
\text { micrometers. }\end{array}$ & $\begin{array}{l}\text { Particles with } \\
\text { aerodynamic } \\
\text { diameters smaller }\end{array}$ & $\begin{array}{l}\text { Particles with } \\
\text { aerodynamic diameters } \\
\text { smaller than } 0.1 \\
\text { micrometers. }\end{array}$ \\
& $\begin{array}{l}\text { than } 2.5 \\
\text { micrometers. }\end{array}$ & \\
\hline
\end{tabular}

The smaller the size the bigger the spatial variability. Nevertheless there is a level for fractions in cities (urban background) and a location-specific local value (e.g. nearby highly frequented streets). Both of them can differ significantly from each other whereas the local one has potential for the local filtration [8].

\subsection{Arrangements}

There are Air Pollution Control Plans for many German cities which refer to the special geographic, political and infrastructural conditions. The arrangements differ in regard of their costs and their efficiency. However there is not always a direct causality between the arrangement and the reduction potential. A few of these projects have a strong influence on user behaviour (e.g. speed limits) $[9,10]$. The total load differs regarding to the local conditions - in agglomeration areas the road traffic (e.g. combustion engines, tyre abrasion and brake dust, road salt) is responsible for most of the pollution [2]. Not all of the appointed arrangements achieved the expected results. So, for example, the erosion attempts had just a marginal impact [11]. 
Using flowering plants is not as effective as expected because they did not durably fix the particles. Leaves and other parts of the plants act as a physical barrier and decelerate the particles [4]. This way, the particulates deposit via sedimentation on the plant parts [4] but due to re-suspension they get back in the air. In addition the potential for filtering fine dust depends on various physiological and chemical characteristics referring to the used plants and the composition [12]. Moreover thick vegetation is able to build ventilation barriers and lead to a higher fine dust concentration [13]. Also the inner-city vegetation suffers vital damage as a result of prevailing diseases, pollution load (not industrial-resistant groves) and climate change which have a negative influence on their potential to bind particulate matter.

As a result of laboratory tests at the University of Bonn (Germany) the experts found that moss is excellent in fixing pollutants [7]. Due to its specific physiologic features moss is strictly different from flowering plants. It does not have a distinctive circulation system to convey water and nutrients from the soil into all parts of the plant. As a result moss needs to gather the required nutrients out of the air. Thus it is called "cation exchanger". The surfaces own the ability for electrostatic charging. Contrary to the moss fine dust and compounds of nitrogen oxide carry a negative charge. As a result forces of attraction and bounding arise which allow the moss to accumulate the substances and convert them into phytomass. According to Frahm and Sabovljevic [7] moss has a bacterial film on its surface which absorbs inorganic compounds and accumulate them in their organic material. In laboratory tests this double-stage process was proven and in addition a retention rate for particulate matter could be measured (20gram $\mathrm{PM} / \mathrm{m}^{2} /$ year).

\subsection{Conclusion}

Due to more than 50 studies and research reports conditions should be developed which embrace both fractionation and emission sources. Especially studies from the Lancaster Environment Center, the University of Applied Science Dresden, the "Fachvereinigung Bauwerksbegrünung e.V". (FBB), the "Forschungsgesellschaft Landschaftsentwicklung Landschaftsbau e.V." (FLL) and the Federal Ministry for the Environment, Nature Conversation, Building and Nuclear Safety were included. They all recommend vertical greening as an arrangement for air pollution control. For example the Lancaster Environment Center simulated that such models are able to reduce 30 per cent of fine dust in urban canyons [14]. The University of Applied Science Dresden validated the fixation on leaf surfaces in outside test beds using ivy (Hedera helix) in Leipzig and Dresden (Germany) [15].

\section{Compounds of Nitrogen Oxide $\left(\mathrm{NO}_{\mathrm{x}}\right)$}

Nitrogen oxides $\left(\mathrm{NO}_{\mathrm{x}}\right)$ belong to reactive compounds of nitrogen which consists of nitrogen and oxygen. 


\subsection{State of knowledge}

The exposure of these compounds is based on the reaction from oxygen and ozone. Nitrogen oxides emerge at the combustion of fossil fuels, lumber and waste. In agglomeration areas road traffic is the largest emitter of $\mathrm{NO}_{\mathrm{x}}-\mathrm{Compounds}$ [2].

\subsection{Arrangements}

Since the 1970s the air quality in relation of nitrogen oxides has improved because of the use of catalysts. The so-called SCR-catalysts convert toxic nitrogen oxides into innocuous atmospheric nitrogen. With the help of intelligent traffic light circuits and the establishment of emission zones or bypasses an attempt is being made to relocate the nitrogen oxides out of the cities into the surroundings [16].

\subsection{Conclusions}

The efforts to reduce the toxic nitrogen oxides result in decreasing the emission. So in comparison to year 1976 the emissions were diminished by 49 per cent [16]. Despite this fact the annual limit value as well the hourly limit values for $\mathrm{NO}_{2}$ from 2010 have been exceeded consistently [17]. In consequence of the enormous volume of traffic there will be no further reduction [18]. Whereby using filter technology does not solve the problems.

Because of reducing the nitrogen oxide content up in the air plants are a possible solution. They are able to absorb nitrogen oxides from the ambient air by natural metabolic processes. The higher the vitality the higher is the absorbing capacity [19].

\section{Description of solution: CityTree}

Building on previous studies and in cooperation with the professorships of innovative cultivation techniques, vegetable gardening and greenhouse management of the University of Applied Science Dresden, the Institute of Agricultural System Technology and the Institute of Building Theory of the University of Technology Dresden a fully free-standing planting system was developed.

The so-called CityTree has a semi permeable and flow-optimised structure. Because a ground anchoring is not required the construction can be placed at many location. To lift the natural capacities a sophisticated structure with automated irrigation, water and energy supply was created. This enables the positioning in areas with high air pollutant concentration. Depending on the prevailing wind direction, the exposure to pollutant emitters and the sun the CityTree is aligned and planted. Therefore an algorithmic analysis is carried out to achieve an excellent effectiveness.

By courtesy of intelligent selection and positioning of the used plant matter and the so created planting concept leads to a nitrogen oxides reduction up to 10-15 per cent and a fine dust reduction up to $20-25$ per cent [19]. The planting concept 
consists of variously structured plants with smooth and raw surfaces, needles and hair, tall and small leaves.

Furthermore moss is used as an optimal substrate in which the vascular plants flourish. This way synergy effects and symbioses are created. The chosen structures of the vascular plants are able to reduce wind speed and PM 10-particles. The particles of the fraction PM 5.5 and PM 0.1 are attracted, bounded and converted into phytomass by the moss. As a consequence all fractions of fine dusts are fixed and not able to get back into the air. The systems living components lead to an excellent fixing of nitrogen oxide compounds because of their better quality and vitality. This way the CityTree is able to contribute to more intelligent and sustainable cities.

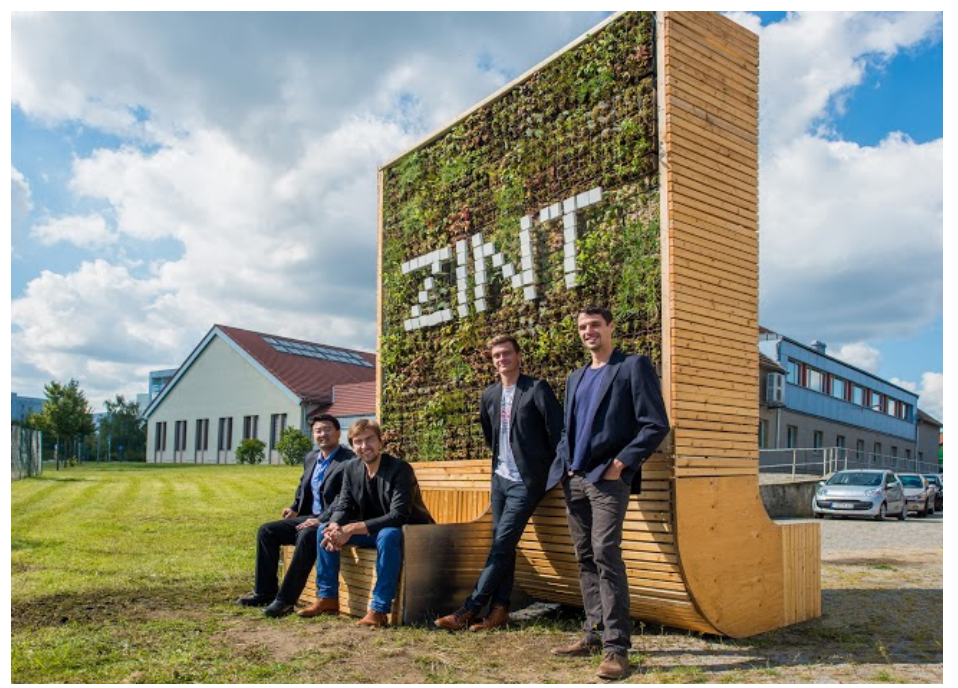

Figure 1: The Green City Solutions team in front of the CityTree.

\section{Differentiation to the state of the art}

Façade greening is reducing the air pollution by fixing fine dust and nitrogen dioxide. The much greater problem is the existence of local hotspot areas. So far the vertical greening cannot be used effectively in the hotspot areas due to the city's ownership structure. Additionally there are restrictions regarding fire prevention. The fully free-standing construction solves these problems.

For the optimally flow-optimized positioning flow analyses were conducted and already used by urban development. The basic component of the advancement in contrast to other flat irrigation systems is the semi permeable single-top irrigation system. Because of being sophisticated designed and an adaptable street furniture the CityTree can be placed in optimum harmony with existing buildings and structures. 
The CityTree combines all of the mentioned individual aspects by using plants to improve the air quality. Placed in urban areas the independent system is able to shape the airflow and reduce the air load. In contrast to previous approaches the vertical plant wall is able to supplement the existing vegetation and diminish the air load in a street immediately. Due to the growth of the plants and the possible pyrolysis of the clippings within five years the CityTree bounds more carbon dioxide than it requires for the production. Pyrolysis converts the cutting waste and thus prevents the carbon dioxide from re-entering the atmosphere.

\section{Site selection}

Geographic information systems provide the possibility to link various locationbased information. Therefore different layers were used for modelling a load situation for every type of place. The objective is to determine the best location and arrangement of the system.

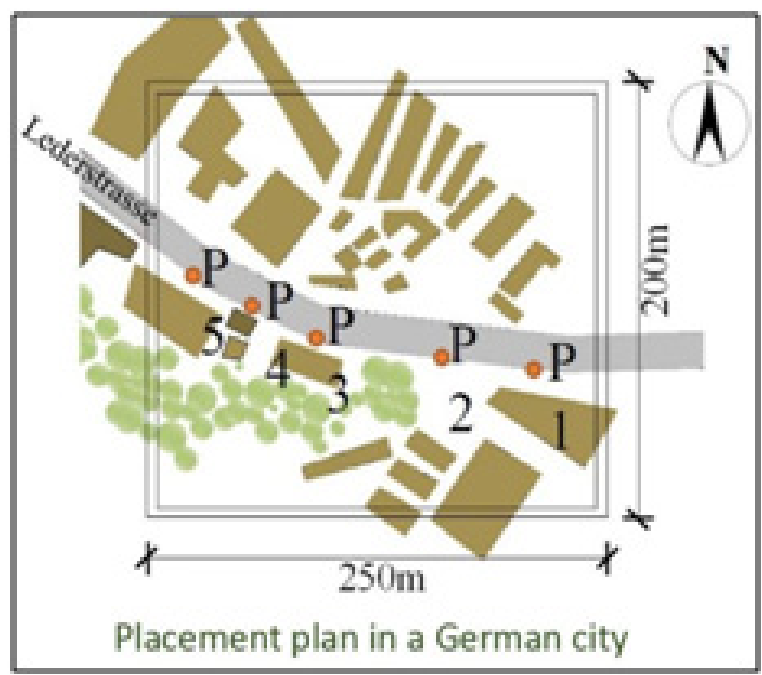

Figure 2: Placement plan in a German city.

\section{Advancement: the "plant filter"}

The automated, patented and TÜV approved system is unique in the way it combines the functional planting, the necessary technical infrastructure and associated analysis technology. Technically the CityTree is characterised by:

- Each single plant is growing in moss which serves as a substrate (no soil required). Thus a symbiosis is formed in each pot. 


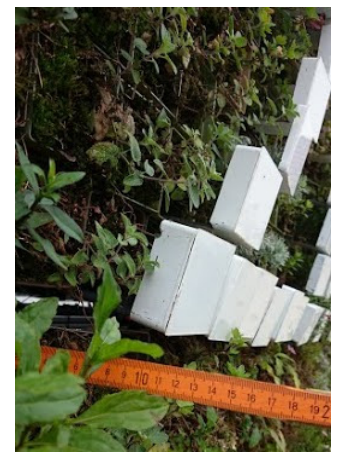

Figure 3: Close-up of the moss and the plants.

- The CityTree has a fully-automated water and nutrient supply system.

- The single pots exhibit a determined small distance to each other. Thus creates a screen structure permeable to air which assist the sedimentation of fine dust and prevent aeration barrier.

- The irrigation of the single pot system with 1.682 ventilates supplies an excellent watering for every single plant.

- The supply system allows an easy data transfer and maintenance is reduced. The system integrates up to 72 sensors.

- The system is equipped with photovoltaic system to guarantee the supply of the electronic components in the control and steering circuit.

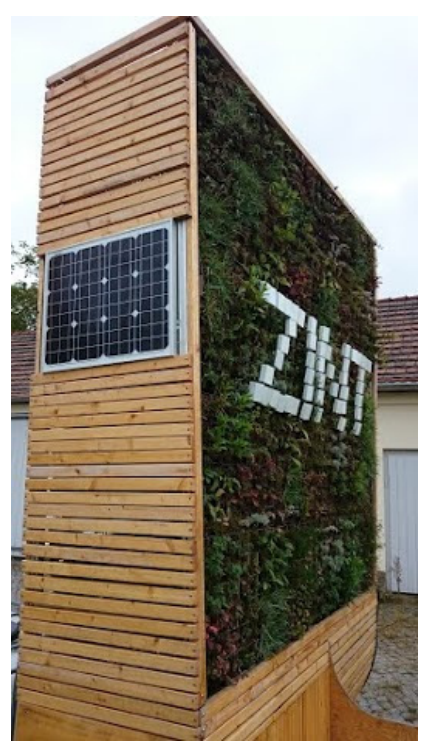

Figure 4: The prototype of the CityTree with wood panelling and the photovoltaic system. 
- To prevent vandalism expanded metal was used for cladding the system.

- On both sides a wooden bench was included. Thus the CityTree is an attractive street furniture.

- As demonstrated in recently studies natural green supports stress reduction. Evergreen plants determine an all-year recreation effect and provide the formation of a sustainable society.

- The dimensions of the CityTree are 2.9 metres $\times 3.75$ metres $\times 0.65$ metres.

- Due to the evaporation the surrounding is cooled up to 15 degrees.

- A sustainable rainwater management enables an expandable tank capacity.

- Thus an effective contribution towards adapting to climate change is generated. The authors demonstrated that fine dust absorbing moss can be combined with covering plants to form a symbiosis to enhance the air cleaning capacity of vertical greening. Cultivated in a freestanding vertical structure the space efficient construction gives a higher degree of freedom for positioning than conventional facade greening. Thus this type of vertical plant structure can be positioned by the help of CFD analyses to optimize the transport of particles to the cleaning surface. This approach can contribute to a significantly better air quality in cities especially in "street canyons".

All in all not just projects like ours are needed but also events like the Air Pollution Conference 2015 organised by the Wessex Institute. It is necessary to tell the general public about the existing problems as well as possible solutions. Thus common platforms are a substantial component to bring experts in the theoretical and practical fields together. Being already the 23rd Annual Meeting, the conference has evidenced its necessity.

\section{References}

[1] World Health Organisation (WHO). WHO Air quality guidelines for particulate matter, ozone, nitrogen dioxide and sulfur dioxide, Global update 2005. Summary of risk assessment, Schweiz, 2006, Online. http://whqlibdoc.who.int/hq/2006/WHO_SDE_PHE_OEH_06.02_eng.pdf

[2] Umweltbundesamt. Feinstaub, (Federal Environment Agency) http://www.umweltbundesamt.de/themen/luft/luftschadstoffe/feinstaub

[3] Pregger, T. \& Friedrich, R., Anthropogenic Particulate Matter Emissions in Germany (Chapter 2.3.6). Emission of Air Pollutants - Measurements, Calculations and Uncertainties (GENEMIS EUROTRAC-2 Subproject Final Report), ed. R. Friedrich \& S. Reis, VDI Springer Verlag: Berlin and Heidelberg, pp. 103-111, 2004.

[4] Kappis, C. et al., Studie zum wissenschaftlichen Erkenntnisstand über das Feinstaubfilterungspotential (qualitativ und quantitativ) von Pflanzen, 2007, Online.

http://www.ble.de/SharedDocs/Downloads/03_Forschungsfoerderung/Fein staubstudie.pdf? _ blob=publicationFile

[5] Klingner, M., Sähn, E., Anke, K., Holst, T., Rost, J., Mayer, H. \& Ahrens, D. Reduktionspotenziale verkehrsbeschränkender Maßnahmen in Bezug zu 
meteorologisch bedingten Schwankungen der PM10- und NOxImmissionen. Gefahrstoffe - Reinhaltung Luft, 66 (7/8), pp. 326-334, 2006.

[6] Kryzanowski, M., Kuna-Dibbert, B. \& Schneider, J. (eds.). Health effects of transport-related air pollution: Denmark, 2005.

[7] Frahm, J. P. \& Sabovljevic, M., Feinstaubreduzierung durch Moose, Nees Institut für Biodiversität der Pflanzen: Bonn, 2007.

[8] Draheim, T., Die räumliche und zeitliche Variabilität der PM 10Schwebstaubkonzentration in Berlin unter Berücksichtigung der Großwettertypen, Geographischen Institut der Humboldt-Universität zu Berlin: Berlin, 2005.

[9] Diegmann, V., Pfäfflin, F. \& Wiegand, D. G., Verkehrliche Maßnahmen zur Reduzierung von Feinstaub - Möglichkeiten und Minderungspotenziale, 2006, Online.

http://www.umweltbundesamt.de/sites/default/files/medien/publikation/lo ng/3259.pdf

[10] Builtjes, P., Jörß, W., Stern, R. \& Thelocke, J., Strategien zur Verminderung der Feinstaubbelastung, 2012, Online.

http://www.umweltbundesamt.de/publikationen/strategien-zur-verminder ung-feinstaubbelastung

[11] Koschutnig, W., Ehrenberg, C. \& Höflinger, W., Untersuchungen diffuser Staubemissionen an befestigten Straßen in Wien; Bestimmung des Staubbelages (sL-Wert) vor und nach der Straßenreinigung (Chapter 2). IUTA-Bericht Nr. LP 26/2005. Untersuchung zur Abschätzung der Wirksamkeit von Nassreinigungsverfahren zur Minderung der PM10Immissionen am Beispiel der Corneliusstraße, Düsseldorf, ed. A. John, A. Hugo, H. Kaminski \& T. Kuhlbusch, Institut für Energie- und Umwelttechnik e. V. (IUTA): Duisburg, p. 18.

[12] Roloff, A., Stadt- und Straßenbäume der Zukunft - welche Arten sind geeignet?, ed. Forstwiss. Beitr. Tharandt Beih. 14: Dresden, pp. 173-187, 2013.

[13] Thönnessen, M., Staubfilterung und immissionshistorische Aspekte am Beispiel fassadenbegrünenden Wilden Weines (Parthenocissus tricuspidata). Umweltwissenschaften und Schadstoff-Forschung, Vol. 18 (Issue 2), pp. 5-12, 2006.

[14] Pugh, T.A.M., MacKenzie, R.A., Wyatt, D.J. \& Hewitt, N.C., Effectiveness of Green Infrastructure for Improvement of Air Quality in Urban Street Canyons, American Chemical Society: Lancaster Environment Centre, Lancaster University, Lancaster, U.K., LA1 4YQ. Environ. Sci. Technol., 46(14), pp. 7692-7699, 2012.

[15] Schröder, F. G., Wolter, S. \& Wolter, A., Abschätzung des Leistungspotentials vertikal begrünter Flächen, basierend auf einem nachhaltig ökologisch nutzbaren Pflanzensystem mit Regenwassermanagement, 2011, Online

http://www.htw-dresden.de/fileadmin/userfiles/land/pdf/Gartenbau/ Abschlussbericht-nachhaltige_Pflanzensysteme2011.pdf 
[16] Bayerische Staatskanzlei, J., JUPO Bayern, 2014, Online. http://www.jupobayern.de/natur-pur/klima-freundlich/stickstoffoxide

[17] Graff, A,. Luftqualität 2013 - Vorläufige Auswertung, Dessau - Roßlau: Umweltbundesamt, 2014.

[18] Bauer, A; Bundesanstalt für Straßenwesen, 2013. ACE LENKRAD. Online. http://www.ace-online.de/der-club/ace-lenkrad/verkehr-und-umwelt/ hintergrundberichte/interview-anja-baum-umweltschutz.html

[19] Klippel, N. \& Jazbec, R., Pflanzen filtern Feinstaub und Stickoxide, Illnau: Umwelt Perspektiven, 2009. 